\title{
Assessment of Knowledge Application in Banking Sector of Sudan: Case Study Farmer's Commercial Bank
}

\author{
Rayan Abdelgader Elhassan \\ Sudan Academy for Banking \& Financial Science, Khartoum, Sudan \\ Email: Ryanabdelgader@gmail.com
}

\author{
Adil Yousif \\ Najran University, Faculty of Arts and Science, Sharourah, Kingdom of Saudi Arabia \\ Email: ayalfaki@nu.ed.sa
}

\section{TajElsir Hassan Suliman}

Sudan Academy for Banking \& Financial Science, Khartoum, Sudan

Email: tagsir@sabfs.edu.sd

Received: 17 April 2021; Accepted: 20 May 2021; Published: 08 August 2021

\begin{abstract}
Knowledge management is one of the contemporary developments that ensure today's institutions generate, distribute and apply knowledge to help in administrative decision making, encourage creativity, increasing competitiveness and improving their performance. The study aimed to identify the degree of application of knowledge management concept in Sudanese banks, "Case study: Commercial Farmer's Bank". The study focuses on knowledge management and the statistical differences related to gender, age, academic qualification and period of service at the bank. To achieve the aim of the study, the descriptive analytical approach was used. The research relied on the questionnaire as the main tool for data collection. The study population consisted of bank employees in their various positions. A total of 60 questionnaires were distributed, of which 58 were returned for statistical analysis. The results of the study followed standard methodology based on the state of the arts researches. The study found that the degree of application of knowledge management was medium in the field of knowledge creation and acquisition, reaching $68 \%$ and high in the field of knowledge storage $74 \%$, knowledge sharing $76 \%$ and knowledge application $77 \%$. The results also showed that there were no statistical differences related to gender, age, academic qualification and period of service.
\end{abstract}

Index Terms: Knowledge management, Banking Sector, Knowledge Application, Organization Performance

\section{Introduction}

Knowledge has been recognized as one of the most critical resources for all types of organizations, it's a source of creativity and innovation and one of the main factors for organizations success especially as it's the initiator and catalyst for development and achievement[1-4]. Therefore, the organizations that seek to achieve a good performance and gain a sustainable competitive advantage should take care of this essential resource[5-7]. Knowledge management has become one of the strategies adopted by various organizations to improve their activities; knowledge management is about managing the corporation's knowledge through a systematically and organizationally specified process for acquiring, organizing, sustaining, applying, sharing and renewing both the tacit and explicit knowledge of employees to enhance organizational performance and create value[8-11]. Knowledge management processes play an important role as potential enablers of working skills and to improve the capacity of the teams to enhance the ways as they share knowledge and the tools that they use. One of the key benefits of introducing knowledge management in organizations is its positive impact on organizational performance[12-14].

Knowledge management is a multidisciplinary concept so banks are not isolated from this concept, knowledge management is a viable means in which banks could improve their services through the creation of an organizational culture that support sharing of knowledge and experiences within the bank[15]. Banks need to become efficient in knowledge management to preserve and leverage knowledge in banking operations. This research tries to identify the extent to which knowledge management is applied at Sudanese banks[16-18]. 
Knowledge management has emerged as one the most important areas in management practices. Most decisions in banking sector are knowledge based, through knowledge management, employees can access, store and share various knowledge, as well as work to renew knowledge and exchange ideas and experiences at various levels of administration[19-21]. KM simplifies the delivery of effective information that are used in institution's processes from planning, consulting and decision making[22-24]. The study aimed to identify the degree of application of knowledge management concept in Sudanese banks, "Case study: Commercial Farmer's Bank". The study focuses on knowledge management and the statistical differences related to gender, age, academic qualification and period of service at the bank. To achieve the aim of the study, the descriptive analytical approach was used. The research relied on the questionnaire as the main tool for data collection. Despite the importance of knowledge management there is a lack of studies on the application of knowledge management in Sudanese banks. The research questions include: to what extent does farmer's commercial bank apply knowledge management? And are there any statistical differences relate to demographics data. The objective of the study is to shed the light on knowledge management concept and it processes[25, 26]. Furthermore, to identify the extent to which knowledge management is applied at Farmer's commercial bank and the statistical differences that relates to demographics data. The research significance lies on the importance of the subject which is knowledge management, KM can lead to performance improvements which have a positive effect to the bank. The research contributes in helping the staff to realize the concept of KM and its importance, the research also provides helpful information for decision makers that can be used in planning and strategies setting[23, 27, 28]. This paper has five sections, section two review the current literature. Section three describe the research methodology. Section four describe the results and analysis. We concluded in section five.

\section{Related Works}

In (2010) Charles JAMES KATUA presents A Framework for Applying Knowledge Management in Organizations[29]. The study aimed to find out how the organization went about capturing, disseminating, applying and creating knowledge, the four KM processes. From the results obtained through the statistical analysis it is evident that $\mathrm{KM}$ is being practiced at a minimal level. A general conclusion based on the findings obtained indicated that the level of KM in organizations was very low; to help organizations benefit from KM initiatives a framework is developed to assist organizations in applying knowledge management in their respective organizations[29]. A study by Joach et.al (2011) entitled: knowledge management practices by commercial banks in [30]. The objective of the study was to determine the extent to which commercial banks in Kenya have adopted knowledge management as well as to determine the various knowledge management practices by these banks the study used primary data collected through questionnaires with open and closed ended questions. The findings of the study revealed that most of the banks did not have a knowledge management strategy in place, despite the high level of appreciation of the concept of knowledge management[30]. Nasser (2012) presented a study entitled: knowledge management and the SECI model. The aim of this study was to investigate the use of the SECI model by Egyptian banks and its effect on innovation[31]. Therefore, the use of each process of SECI was investigated, followed by aspects of innovation in banks, and finally the relationship between the SECI model and innovation was examined. The four processes of the SECI model (socialization, externalization, combination and internalization) and two types of innovation (product and process) were considered in this study[31]. A study of Omer Mohammed (2015) entitled: Knowledge Management in Banks and Financial Sector Bangladesh perspectives: The aim of the study was to asses KM practices in Banks and financial institutions in Bangladesh. The more specific objectives of the study were to ascertain the followings: To analyze the different KM practices used in different Banks and financial institutions (FI) of Bangladesh. To identify and analyze similarities and differences between the KM priorities in Banks \& FI ${ }^{e e} \mathrm{~S}$ of Bangladesh to explore the present state of $\mathrm{KM}$ usage and practices in Banks \& $\mathrm{FI}^{\mathrm{e}} \mathrm{S}$ of Bangladesh. The study reveals that there are few KM practices in Bank and FI'S of Bangladesh. In Khoualdi et.al (2019) a study amid at identifying the challenges of implementing knowledge management in the banking sector and determining the levels of competitive advantage in the banking sector in Jeddah Kingdom of Saudi Arabia. The study also aims at identifying the contributions and added value associated with the implementation of knowledge management in attaining competitive advantage. The analytical descriptive approach was used as a research approach. To collect data, a questionnaire was distributed to achieve the research objectives. The study sample included 300 individuals working in the banking sector in Jeddah. Results of the study show the impact knowledge management on the achievement and improvement of competitive advantage, on customer satisfaction, and on operational excellence.

Most of the previous studies focused on knowledge management and its effect on creating creativity and creating a competitive advantage[32-34]. The current study agreed with previous studies as it aimed to identify the concept of knowledge management, its importance and the importance of its application in institutions. It also agreed with previous studies in the use of the analytical descriptive approach and the questionnaire as a study tool. The current study differed from previous studies as it used the four basic processes of knowledge management to assess the application of the concept of knowledge management in Sudanese banks, and that the study population included all employees working in the bank, not only those with administrative and supervisory positions. 


\section{Research Methodology}

This section aimed to explain the methodology of the study and the procedures and tools used to achieve its objectives.

\subsection{Study Approach}

Based on the nature of the study and the objectives it seeks to achieve, the researcher used the analytical descriptive method, which is based on the study of the phenomenon as it is in fact and is concerned as a precise description and expressed in quantity and quality. This approach not only collects information about the phenomenon, but rather analyzes and interprets it in order to arrive at conclusions.

\subsection{Study Population}

The study was applied at farmer's commercial bank in 2019. The study population consisted of the employees of farmer's commercial bank with their different positions, where 60 questionnaires were distributed and 58 were returned.

\subsection{Study Instrument}

To achieve the goal of the study, the researcher relied on the questionnaire as a main tool to collect data. The questionnaire consisted of two sections; the first section is the personal information (gender, age, academic qualification, and years of experience). The second section was the knowledge management processes which consisted of 25 statements distributed in four dimensions (knowledge acquisition, knowledge storage, knowledge dissemination, application of knowledge).

\subsection{Quality of Measures}

As the questionnaire supposed to provide accurate and repeatable measures of the research hypotheses, validity and reliability tests were used to establish the quality of any social research.

\subsection{Reliability Test}

Reliability means that the scale gives the same results if it is re-applied to the same sample. The researcher verified the reliability of the questionnaire through the Cronbach alpha coefficient and the results were as in the table below.

Table 1. Cronbach Alpha Coefficient

\begin{tabular}{|l|l|l|l|}
\hline Axes & No & Reliability & Validity \\
\hline knowledge acquisition and creation activities & 6 & 0.710 & 0.842 \\
\hline knowledge storage activities & 6 & 0.760 & 0.872 \\
\hline knowledge sharing activities & 7 & 0.764 & 0.871 \\
\hline knowledge application activities & 6 & 0.721 & 0.849 \\
\hline All axes & 25 & 0.897 & 0.947 \\
\hline
\end{tabular}

Validity: The positive square root of Alpha Cronbach

\section{(i) Validity Test}

To ensure the validity and objectivity of the study instrument, the validity of the questionnaire was tested. This means that the instrument is valid for measuring what it aims to measure. The researcher presented the questionnaire to three arbitrators who are specialists in the field. The researcher responded to their opinions and made the necessary changes in the light of the recommendations offered.

The results from Table 1 shows that the value of the Cronbach alpha coefficient was high where the values were $(0.710,0.760,0.764$, and 0.721$)$ and the value of the alpha coefficient for all the axes of the questionnaire were (0.897). The value of validity was also high for all questionnaire axes where the values were $(0.842,0.872,0.871$, and 0.849$)$; the value of the overall validity was high (0.947) which means that the instrument is valid and reliable.

\section{(ii) Spearman Correlation Analysis}

Spearman rank correlation is a test that is used to measure the degree of association between variables. Spearman rank correlation test does not assume any assumptions about the distribution meaning that the above data has a nonnormal distribution. Spearman Correlation analysis was used to determine the relationships between the various knowledge management practices, which are identified as knowledge acquisition, knowledge storage, knowledge sharing and knowledge application. The table below shows their relationships.

(iii) Correlation Coefficient 
The correlation coefficient between all axes was calculated to study the relationship between them, and know which factors are stronger and less relate. The correlation coefficient is a statistical measure that calculates the strength of the relationship between the relative movements of two variables. The values range between -1.0 and 1.0. A calculated number greater than 1.0 or less than -1.0 means that there was an error in the correlation measurement. A correlation of -1.0 shows a perfect negative.

Table 2. Spearman Correlation Matrix

\begin{tabular}{|l|l|l|l|l|}
\hline Correlations & $\mathrm{t} 1$ & $\mathrm{t} 2$ & $\mathrm{t} 3$ & $\mathrm{t} 4$ \\
\hline $\mathrm{t} 1$ & 1.000 & $.764 * *$ & $.533^{* *}$ & $.553^{* *}$ \\
\hline $\mathrm{t} 2$ & $.764 * *$ & 1.000 & $.514^{* *}$ & $.685^{* *}$ \\
\hline $\mathrm{t} 3$ & $.533^{* *}$ & $.514^{* *}$ & 1.000 & $.638^{* *}$ \\
\hline $\mathrm{t} 4$ & $.553^{* *}$ & $.685^{* *}$ & $.638^{* *}$ & 1.000 \\
\hline
\end{tabular}

From Table 2 the value of spearman correlation coefficient for the four factors were positive and it is between 0.5 and 0.7 indicates that all the knowledge management practices are significantly correlated to each other.

\section{Data Analysis \& Hypothesis Testing}

This section presents the analysis of data collected by questionnaire the section also aims to test the hypotheses of the study using the appropriate statistical tests using the statistical packages of social studies SPSS. The following subsection describes the frequencies and percentages of respondents' responses to knowledge management processes.

\subsection{Frequencies and percentages of respondents' responses to knowledge creation and acquisition activities}

Table 3. Frequencies and percentages of respondents' responses to knowledge creation and acquisition activities

\begin{tabular}{|c|c|c|c|c|c|c|c|}
\hline No & $\begin{array}{l}\text { The bank knowledge acquisition and creation } \\
\text { activities }\end{array}$ & Scale & $\begin{array}{l}\text { Strongly } \\
\text { disagree }\end{array}$ & disagree & neutral & agree & $\begin{array}{l}\text { Strongly } \\
\text { agree }\end{array}$ \\
\hline \multirow[b]{2}{*}{1} & \multirow{2}{*}{$\begin{array}{l}\text { The bank concerns with developing abilities } \\
\text { and skills of employees }\end{array}$} & Frequency & 2 & 0 & 5 & 23 & 28 \\
\hline & & Percent & 3.3 & 0 & 8.6 & 39.7 & 48.3 \\
\hline \multirow[t]{2}{*}{2} & \multirow{2}{*}{$\begin{array}{l}\text { The bank concerns with new ideas, thought and } \\
\text { suggestions proposed by employees }\end{array}$} & Frequency & 0 & 1 & 10 & 27 & 20 \\
\hline & & Percent & 0 & 1.7 & 17.2 & 46.6 & 34.5 \\
\hline \multirow[b]{2}{*}{3} & \multirow{2}{*}{$\begin{array}{l}\text { The bank motivate and reward creative } \\
\text { employees }\end{array}$} & Frequency & 1 & 1 & 15 & 23 & 18 \\
\hline & & Percent & 1.7 & 1.7 & 25.9 & 39.7 & 31.0 \\
\hline \multirow[b]{2}{*}{4} & \multirow{2}{*}{$\begin{array}{l}\text { The bank gives its employees the freedom to } \\
\text { organize and carry out their job by methods and } \\
\text { means they believe appropriate }\end{array}$} & Frequency & 1 & 5 & 18 & 21 & 13 \\
\hline & & Percent & 1.7 & 8.6 & 31.0 & 36.2 & 22.4 \\
\hline \multirow[b]{2}{*}{5} & \multirow{2}{*}{$\begin{array}{l}\text { The bank seeks the help of external experts and } \\
\text { specialists to transfer their knowledge and } \\
\text { experience to employees }\end{array}$} & Frequency & 2 & 13 & 24 & 0 & 19 \\
\hline & & Percent & 2.4 & 22.4 & 41.4 & 0 & 32.8 \\
\hline \multirow{4}{*}{6} & \multirow{2}{*}{$\begin{array}{l}\text { The bank is concerned in participating in } \\
\text { conferences and workshops inside and outside } \\
\text { as a method of obtaining knowledge }\end{array}$} & Frequency & 3 & 1 & 6 & 22 & 26 \\
\hline & & Percent & 5.2 & 1.7 & 10.3 & 37.9 & 44.8 \\
\hline & \multirow[t]{2}{*}{ Result of first axes } & Frequency & 1 & 0 & 4 & 29 & 24 \\
\hline & & Percent & 1.7 & 0 & 6.9 & 50.0 & 41.4 \\
\hline
\end{tabular}

From Table 3. above its clear that the bank is concerned with developing abilities and skills of employees, where the percentage of those who approved and strongly approved was $88 \%$. It is also clear that the Bank is concerned with new ideas, thought and suggestions proposed by employees as the percentage of those who approved and approved strongly was $81.1 \%$. While the percentage of the approved and strongly approved for the third statement was $70.7 \%$, The fourth statement, which stated that The bank gives its employees the freedom to organize and carry out their job by methods and means they believe appropriate, the percentage of those who approved and strongly approved was 58.6\%, while the percentage of neutrals and non-approved was $41.3 \%$ and from the researcher's point of view, this indicates that the bank gives freedom but to a limited extent. As for the fifth statement, the percentage of neutral and nonapproved was $63.8 \%$ this indicates that the bank does not seek the help of external experts and specialists to transfer their knowledge and experience to employees. As for the last statement the sample members confirmed that the bank is concerned in participating in conferences and workshops inside and outside as a method of obtaining knowledge where the percentage of respondent who approved and strongly approved was $82.7 \%$.

\subsection{Frequencies and percentages of respondents' responses to knowledge storage activities.}


Table 4. Frequencies and percentages of respondents' responses to knowledge storage activities

\begin{tabular}{|c|c|c|c|c|c|c|c|}
\hline No & The bank knowledge storage activities & Scale & $\begin{array}{l}\text { Strongly } \\
\text { disagree }\end{array}$ & disagree & neutral & agree & $\begin{array}{l}\text { Strongly } \\
\text { agree }\end{array}$ \\
\hline \multirow[b]{2}{*}{1} & \multirow{2}{*}{$\begin{array}{l}\text { The bank saves knowledge in an } \\
\text { accessible way }\end{array}$} & Frequency & 0 & 0 & 6 & 28 & 24 \\
\hline & & Percent & 0 & 0 & 10.3 & 48.3 & 41.4 \\
\hline \multirow[t]{2}{*}{2} & \multirow{2}{*}{$\begin{array}{l}\text { The bank documents new acquired } \\
\text { knowledge for each accomplished project. }\end{array}$} & Frequency & 0 & 0 & 12 & 25 & 21 \\
\hline & & Percent & 0 & 0 & 20.7 & 43.1 & 36.2 \\
\hline \multirow[b]{2}{*}{3} & \multirow{2}{*}{$\begin{array}{l}\text { Employees document problems they face } \\
\text { and methods used to solve these problems } \\
\text { for future benefits. }\end{array}$} & Frequency & 0 & 2 & 9 & 28 & 18 \\
\hline & & Percent & 0 & 3.4 & 15.5 & 48.3 & 31.0 \\
\hline \multirow[b]{2}{*}{4} & \multirow{2}{*}{$\begin{array}{l}\text { In each department, experts' knowledge is } \\
\text { documented and organized it as stories of } \\
\text { success to be used as basis for problem } \\
\text { solving. }\end{array}$} & Frequency & 0 & 7 & 17 & 14 & 20 \\
\hline & & Percent & 0 & 12.1 & 29.3 & 24.1 & 34.5 \\
\hline \multirow[b]{2}{*}{5} & \multirow{2}{*}{$\begin{array}{l}\text { The bank has a comprehensive, adequate } \\
\text { database or (knowledge base) which is } \\
\text { available for all employees }\end{array}$} & Frequency & 1 & 1 & 13 & 20 & 22 \\
\hline & & Percent & 1.7 & 1.7 & 22.4 & 34.5 & 37.9 \\
\hline \multirow{4}{*}{6} & \multirow{2}{*}{$\begin{array}{l}\text { The bank is concern in retaining } \\
\text { employees who have high knowledge to } \\
\text { prevent their transfer to other institutions }\end{array}$} & Frequency & 3 & 2 & 13 & 17 & 23 \\
\hline & & Percent & 5.2 & 3.4 & 22.4 & 29.3 & 39.7 \\
\hline & \multirow[t]{2}{*}{ Result of second axes } & Frequency & 0 & 0 & 10 & 23 & 25 \\
\hline & & Percent & 0 & 0 & 17.2 & 39.7 & 43.1 \\
\hline
\end{tabular}

Table (4-5) shows that the bank saves knowledge in an accessible way, the percentage of those who approved and approved strongly was $89.7 \%$. The second statement, which stated that the bank documents new acquired knowledge for each accomplished project, the percentage of those who approved and strongly approved was $79.3 \%$. Also $79.3 \%$ of the respondents confirmed that employees document problems they face and methods used to solve these problems for future benefits. The fourth statement, which stated that In each department, experts' knowledge is documented and organized it as stories of success to be used as basis for problem solving., the percentage of respondents who approved and strongly approved was58.6\% and the percentage of neutrals and non-approved was $41.4 \%$; from the researcher point of view this shows that the documentation of expert knowledge needs more attention by the bank. The fifth statement, which stated that the bank has a comprehensive, adequate database or (knowledge base) which is available for all employees, has received an approval rate of 72.4\%. As for the Bank's concern in retaining employees who have high knowledge to prevent their transfer to other institutions, the percentage of those who approve and strongly agree with the statement was $69 \%$ while the percentage of neutral and non-approved was $31 \%$ this may indicate that The bank needs more attention to staff retention policies.

\subsection{Frequencies and percentages of respondents' responses to knowledge sharing activities}

Table 5. Frequencies and percentages of respondents' responses to knowledge sharing activities

\begin{tabular}{|c|c|c|c|c|c|c|c|}
\hline No & bank knowledge sharing activities & Scale & $\begin{array}{l}\text { Strongly } \\
\text { disagree }\end{array}$ & disagree & neutral & Agree & $\begin{array}{l}\text { Strongly } \\
\text { agree }\end{array}$ \\
\hline \multirow[b]{2}{*}{1} & \multirow{2}{*}{$\begin{array}{l}\text { Employees don't face difficulty in accessing any } \\
\text { information they need in work }\end{array}$} & Frequency & 4 & 15 & 10 & 18 & 21 \\
\hline & & Percent & 6.9 & 8.6 & 17.2 & 31.0 & 36.2 \\
\hline \multirow[t]{2}{*}{2} & \multirow{2}{*}{$\begin{array}{l}\text { The bank foster and promote training courses to develop } \\
\text { employees' skills in sharing and exchanging new ideas. }\end{array}$} & Frequency & 2 & 3 & 7 & 24 & 21 \\
\hline & & Percent & 3.4 & 5.2 & 12.3 & 42.1 & 36.8 \\
\hline \multirow[b]{2}{*}{3} & \multirow{2}{*}{$\begin{array}{l}\text { Employees don't hesitate to ask for help or advice from } \\
\text { my managers or colleagues at work. }\end{array}$} & Frequency & 1 & 2 & $6 \backslash 5$ & 18 & 32 \\
\hline & & Percent & 1.7 & 3.4 & 8.6 & 31.0 & 55.2 \\
\hline \multirow[b]{2}{*}{4} & \multirow{2}{*}{$\begin{array}{l}\text { employees have enough time to interact and work with } \\
\text { colleagues to discuss work related issues }\end{array}$} & Frequency & 6 & 4 & 8 & 28 & 12 \\
\hline & & Percent & 10.3 & 6.9 & 13.8 & 48. & 20.7 \\
\hline \multirow[b]{2}{*}{5} & \multirow{2}{*}{$\begin{array}{l}\text { The bank general policy encourages employees to present } \\
\text { their new ideas related to their work. }\end{array}$} & Frequency & 1 & 4 & 12 & 27 & 14 \\
\hline & & Percent & 1.7 & 6.9 & 20.7 & 46.6 & 24.1 \\
\hline \multirow[b]{2}{*}{6} & \multirow{2}{*}{$\begin{array}{l}\text { The Bank uses written publications to disseminate } \\
\text { knowledge associated with its activities among employees }\end{array}$} & Frequency & 1 & 1 & 8 & 29 & 19 \\
\hline & & Percent & 1.7 & 1.7 & 13.8 & 50.0 & 32.8 \\
\hline \multirow{4}{*}{7} & \multirow{2}{*}{$\begin{array}{l}\text { The Bank has a means of communication that ensures } \\
\text { professional communication that disseminates the } \\
\text { knowledge associated with activities among Bank } \\
\text { employees at all levels }\end{array}$} & Frequency & 0 & 4 & 5 & 25 & 24 \\
\hline & & Percent & 0 & 6.9 & 8.6 & 43.1 & 41.1 \\
\hline & \multirow[t]{2}{*}{ Result of third axes } & Frequency & 0 & 5 & 4 & 25 & 24 \\
\hline & & Percent & 0 & 8.6 & 6,9 & 43.1 & 41.4 \\
\hline
\end{tabular}

Table 5. shows that the percentage of those who approved and strongly approved for the first statement was $67.2 \%$ while the ratio of neutral and non-approved was $32.7 \%$. It is also clear that the bank foster and promote training courses to develop employees' skills in sharing and exchanging new ideas, with a percentage of approvals reached $78.9 \%$. The third statement, which stated that the employees don't hesitate to ask for help or advice from their managers or colleagues, the percentage of those who approved and strongly approved was $86.2 \%$. $68.7 \%$ of the respondents 
agreed that the employees have enough time to interact and work with colleagues to discuss work related issues. $70 \%$ of respondents show their approval on the fifth statement, which stated that the bank general policy encourages employees to present their new ideas related to their work. And $82.8 \%$ confirmed that The Bank uses written publications to disseminate knowledge associated with its activities among employees. $84.2 \%$ of the respondents show their approval on the last statement which stated The Bank has a means of communication that ensures professional communication that disseminates the knowledge associated with activities among Bank employees at all levels.

\subsection{Frequencies and percentages of respondents' responses to knowledge application activities}

Table 6. Frequencies and percentages of respondents' responses to knowledge application activities

\begin{tabular}{|c|c|c|c|c|c|c|c|}
\hline no & bank knowledge application activities & Scale & $\begin{array}{l}\text { Strongly } \\
\text { disagree }\end{array}$ & disagree & neutral & Agree & Strongly agree \\
\hline \multirow{2}{*}{1} & \multirow{2}{*}{$\begin{array}{l}\text { The bank works to transform knowledge into action } \\
\text { plans. }\end{array}$} & Frequency & 0 & 0 & 10 & 31 & 17 \\
\hline & & Percent & 0 & 0 & 17.2 & 53.4 & 29.3 \\
\hline \multirow[t]{2}{*}{2} & \multirow{2}{*}{$\begin{array}{l}\text { When new methods to improve work emerged, } \\
\text { employees adopt them instantly. }\end{array}$} & Frequency & 1 & 3 & 7 & 29 & 17 \\
\hline & & Percent & 1.8 & 5.3 & 12.3 & 50.9 & 29.8 \\
\hline \multirow[b]{2}{*}{3} & \multirow{2}{*}{$\begin{array}{l}\text { The bank employ knowledge by converting it to new } \\
\text { services }\end{array}$} & Frequency & 0 & 1 & 11 & 22 & 24 \\
\hline & & Percent & 0 & 1.7 & 19.0 & 37.9 & 41.1 \\
\hline \multirow[b]{2}{*}{4} & \multirow{2}{*}{$\begin{array}{l}\text { Employees always use and apply methods gained } \\
\text { during training courses. }\end{array}$} & Frequency & 0 & 1 & 12 & 17 & 27 \\
\hline & & Percent & 0 & 1.8 & 20.7 & 29.8 & 47.4 \\
\hline \multirow[b]{2}{*}{5} & \multirow{2}{*}{$\begin{array}{l}\text { When evaluating the performance of employees, the } \\
\text { extent to which they apply knowledge acquired in their } \\
\text { field of work is taken into account }\end{array}$} & Frequency & 0 & 1 & 13 & 23 & $21^{\prime}$ \\
\hline & & Percent & 0 & 1.7 & 22.4 & 39.7 & 36.2 \\
\hline \multirow{4}{*}{6} & \multirow{2}{*}{$\begin{array}{l}\text { The Bank works to remove difficulties that limit the } \\
\text { ability of employees to apply knowledge }\end{array}$} & Frequency & 3 & 1 & 12 & 30 & 12 \\
\hline & & Percent & 5.2 & 1.7 & 20.7 & 51.7 & 20.7 \\
\hline & \multirow[t]{2}{*}{ Result of forth axes } & Frequency & 0 & 0 & 7 & 26 & 25 \\
\hline & & Percent & 0 & 0 & 12.1 & 45.6 & 42.1 \\
\hline
\end{tabular}

From Table 6. it is clear that the bank works to transform knowledge into action plans, where the percentage of those who approved and approved strongly was $82.7 \%$. It can also be said that when new methods to improve work emerged, employees adopt them instantly, where the percentage of those who approved and approved strongly was $80.7 \%$. As the bank employment of knowledge and converting it to new services, the percentage of approved and strongly approved respondents was 79\%. The fourth statement the percentage of those who approved and approved strongly has reached $77.2 \%$ which stated that employees always use and apply methods gained during training courses. The fifth statement, which stated that When evaluating the performance of employees, the extent to which they apply knowledge acquired in their field of work is taken into account the percentage of those who approved and approved strongly was $75.9 \%$, and It is clear from the sixth statement that the Bank works to remove difficulties that limit the ability of employees to apply knowledge, where the percentage of approved and strongly approved $72.4 \%$.

\subsection{Hypothesis Analysis}

The first hypothesis claims that there is an application of knowledge creation and acquisition processes in the bank.

To answer this, the chi-Square test was used as in Table (4-9) and the results were as follows

Table 7. The First Hypothesis

\begin{tabular}{|c|c|c|c|c|c|}
\hline $\begin{array}{l}\text { To what extent does the bank performs knowledge } \\
\text { creation and acquisition activities? }\end{array}$ & Mean & Std. Deviation & $\begin{array}{l}\text { Pearson Chi- } \\
\text { Square }\end{array}$ & Sig & Result \\
\hline $\begin{array}{l}\text { The bank concerns with developing abilities and skills of } \\
\text { employees }\end{array}$ & 4.29 & 0.899 & 34.552 & 0.000 & $\begin{array}{l}\text { Strongly } \\
\text { agree }\end{array}$ \\
\hline $\begin{array}{l}\text { The bank concerns with new ideas, thought and } \\
\text { suggestions proposed by employees }\end{array}$ & 4.14 & 0.760 & 26.828 & 0.000 & Agree \\
\hline The bank motivate and reward creative employees & 3.97 & 0.898 & 35.103 & 0.000 & Agree \\
\hline $\begin{array}{l}\text { The bank gives its employees the freedom to organize and } \\
\text { carry out their job by methods and means they believe } \\
\text { appropriate }\end{array}$ & 3.69 & 0.977 & 24.759 & 0.000 & Agree \\
\hline $\begin{array}{l}\text { The bank seeks the help of external experts and specialists } \\
\text { to transfer their knowledge and experience to employees }\end{array}$ & 4.03 & 0.837 & 18.552 & 0.000 & Agree \\
\hline $\begin{array}{l}\text { The bank is concerned in participating in conferences and } \\
\text { workshops inside and outside as a method of obtaining } \\
\text { knowledge. }\end{array}$ & 4.16 & 1.040 & 45.966 & 0.000 & Agree \\
\hline Result of first axes & 4.2931 & .74947 & 40.897 & 0.000 & $\begin{array}{l}\text { Strongly } \\
\text { agree }\end{array}$ \\
\hline
\end{tabular}


Table 7. shows the analysis of the first hypothesis, where mean was 4.2931 , standard deviation was 0.74947 , ChiSquare was 40.897 and critical probability Sig was 0.000 , its less than 0.05 its means that, there are significant differences at significant level of 0.05 with $95 \%$ confidence where it was favor for those who responded to strongly agree to the bank application of knowledge acquisition and creation activities.

The second hypothesis claims that there is an application of knowledge storage process in the bank. To answer this, the Chi-Square test was used as in Table 8. and the results were as follows

Table 8. The Second Hypothesis

\begin{tabular}{|l|l|l|l|l|}
\hline $\begin{array}{l}\text { Please show to what extent does the bank perform knowledge } \\
\text { storage activities? }\end{array}$ & Mean & Std. Deviation & $\begin{array}{l}\text { Pearson } \\
\text { Chi-Square }\end{array}$ & Sig \\
\hline $\begin{array}{l}\text { The bank saves knowledge in an accessible way } \\
\text { Result }\end{array}$ & 4.31 & 0.654 & 14.207 & 0.004 \\
agree
\end{tabular}

Table 8. shows the analyses of the second hypothesis, where mean was 4.2586, standard deviation was 0.73890 , Chi-Square was 6.862and critical probability Sig was 0.032, its less than 0.05 its means there are significant differences at significant level of 0.05 with $95 \%$ confidence where it was favor for those who responded to strongly agree to the bank application of knowledge storage activities.

Third Hypothesis claims that there is an application of knowledge sharing process in the bank. To answer this, the chi-Square test was used as in Table 9. and the results were as follows

Table 9. The Third Hypothesis

\begin{tabular}{|c|c|c|c|c|c|}
\hline $\begin{array}{l}\text { Please show to what extent does the bank perform } \\
\text { Knowledge sharing activities? }\end{array}$ & Mean & $\begin{array}{l}\text { Std. } \\
\text { Deviation }\end{array}$ & $\begin{array}{l}\text { Pearson Chi- } \\
\text { Square }\end{array}$ & sig & result \\
\hline $\begin{array}{l}\text { Employees don't face difficulty in accessing any information } \\
\text { they need in work. }\end{array}$ & 3.81 & 1.221 & 20.103 & 0.000 & Agree \\
\hline $\begin{array}{l}\text { The bank foster and promote training courses to develop } \\
\text { employees' skills in sharing and exchanging new ideas. }\end{array}$ & 4.04 & 1.017 & 37.649 & 0.000 & Agree \\
\hline $\begin{array}{l}\text { Employees don't hesitate to ask for help or advice from my } \\
\text { managers or colleagues at work }\end{array}$ & 4.34 & 0.909 & 60.793 & 0.000 & $\begin{array}{l}\text { Strongly } \\
\text { agree }\end{array}$ \\
\hline $\begin{array}{l}\text { employees have enough time to interact and work with } \\
\text { colleagues to discuss work related issues }\end{array}$ & 3.62 & 1.197 & 32.000 & 0.000 & Agree \\
\hline $\begin{array}{l}\text { The bank general policy encourages employees to present } \\
\text { their new ideas related to their work. }\end{array}$ & 3.84 & 0.933 & 35.621 & 0.000 & Agree \\
\hline $\begin{array}{l}\text { The Bank uses written publications to disseminate knowledge } \\
\text { associated with its activities among employees }\end{array}$ & 4.10 & 0.831 & 51.310 & 0.000 & Agree \\
\hline $\begin{array}{l}\text { The Bank has a means of communication that ensures } \\
\text { professional communication that disseminates the knowledge } \\
\text { associated with activities among Bank employees at all levels }\end{array}$ & 4.19 & 0.868 & 27.655 & 0.000 & Agree \\
\hline Result of the third axes & 4.1724 & 0.90103 & 27.655 & 0.000 & Agree \\
\hline
\end{tabular}

Table 9. shows the analysis of the third hypothesis, where mean was 4.1724, standard deviation was 0.90103 , ChiSquare was 27.655and critical probability Sig was 0.000 , its less than 0.05 its means there are significant differences at significant level of 0.05 with $95 \%$ confidence where it was in favor of those who responded to agree to the bank uses knowledge sharing activities.

The fourth hypothesis claims that there is application of knowledge application process in the bank. To answer this, the chi-Square test was used as in Table 10. and the results were as follows 
Table 10. The Fourth Hypothesis

\begin{tabular}{|l|l|l|l|l|l|}
\hline $\begin{array}{l}\text { To what extent does the bank perform knowledge } \\
\text { application activities? }\end{array}$ & Mean & $\begin{array}{l}\text { Std. } \\
\text { Deviation }\end{array}$ & $\begin{array}{l}\text { Pearson } \\
\text { Chi- } \\
\text { Square }\end{array}$ & sig & result \\
\hline $\begin{array}{l}\text { The bank works to transform knowledge into action } \\
\text { plans. }\end{array}$ & 4.12 & 0.677 & 11.828 & 0.003 & Agree \\
\hline $\begin{array}{l}\text { When new methods to improve work emerged, } \\
\text { employees adopt them instantly. }\end{array}$ & 4.02 & 0.896 & 47.298 & 0.000 & Agree \\
\hline $\begin{array}{l}\text { The bank employ knowledge by converting it to } \\
\text { new services }\end{array}$ & 4.19 & 0.805 & 23.517 & 0.000 & Agree \\
\hline $\begin{array}{l}\text { Employees always use and apply methods gained } \\
\text { during training courses. }\end{array}$ & 4.23 & 0.846 & 24.614 & 0.000 & Strongly agree \\
\hline $\begin{array}{l}\text { When evaluating the performance of employees, } \\
\text { the extent to which they apply knowledge acquired } \\
\text { in their field of work is taken into account }\end{array}$ & 4.10 & 0.810 & 20.621 & 0.000 & Agree \\
\hline $\begin{array}{l}\text { The Bank works to remove difficulties that limit } \\
\text { the ability of employees to apply knowledge }\end{array}$ & 3.81 & 0.963 & 45.276 & 0.000 & Agree \\
\hline Result of fourth axes & 4.2982 & 0.68046 & 11.474 & 0.003 & Strongly agree \\
\hline
\end{tabular}

Table 10. shows the analyses of the fourth hypothesis, where mean was 4.2982, standard deviation was 0.68046 , Chi-Square was 11.474 and critical probability Sig was 0.003 , its less than 0.05 its means there are significant differences at significant level of 0.05 with $95 \%$ confidence where it was in favor of those who responded to strongly agree to the bank uses knowledge application activities.

\subsection{Summary of research hypotheses}

Table 11. The Summary of research hypotheses

\begin{tabular}{|c|c|c|c|c|c|}
\hline Hypothesis & Mean & Std. Deviation & Pearson Chi-Square & importance & Sig \\
\hline Knowledge creation and acquisition & 4.2931 & 0.74947 & 40.897 & 69 & 0.000 \\
\hline Knowledge storage & 4.2586 & 0.73890 & 6.862 & 74.6 & 0.032 \\
\hline Knowledge sharing & 4.1724 & 0.90103 & 27.655 & 76.8 & 0.000 \\
\hline Knowledge application & 4.2982 & 0.68046 & 11.474 & 77.9 & 0.003 \\
\hline Result of fourth axes & 4.25 & 0.76 & 21.72 & 74.57 & 0.0008 \\
\hline
\end{tabular}

From Table 11. the results of the analysis show that the majority of the sample members strongly agree with all the statements that measure the first hypothesis with a relative importance of $69 \%$ and a significant level of 0.0000 in favor of those who agree with a high degree. It's concluded that the hypothesis of the study, which stated that there is an application of the processes of creating and acquiring knowledge, has been validated in all statements that measure the hypothesis, meaning that there is an application of knowledge creation and acquisition process at a rate of $69 \%$.

Table 11. shows the results of the analysis revealed that the majority of the study population strongly agrees with all the statements that measure the second hypothesis with a relative importance of $74 \%$ and a significant level of 0.032 in favor of those who strongly agree. It's concluded that the hypothesis of the study, which stated that there, is an application of the processes of creating and acquiring knowledge has been validated in all statements that measure the hypothesis, meaning that there is an application of knowledge storage processes within the bank at a rate of $74 \%$.

The results of the analysis as shown in Table 11. showed that the majority of the study population agrees with all the statements that measure the third hypothesis with a relative importance of $76.8 \%$ and a significant level of 0.000 in favor of those who agree. It's concluded that the hypothesis of the study, which stated that there, is an application of the processes of creating and acquiring knowledge has been validated in all statements that measure the hypothesis, meaning that there is an application of knowledge sharing processes within the bank at a rate of $76.8 \%$.

The results of the analysis in Table 11. revealed that the majority of the study population strongly agrees with all the statements that measure the fourth hypothesis with a relative importance of $77 \%$ and a significant level of 0.003 in favor of those who strongly agree. It's concluded that the hypothesis of the study, which stated that there, is an application of the processes of creating and acquiring knowledge has been validated in all statements that measure the hypothesis, meaning that there is an application of knowledge application processes within the bank at a rate of $77 \%$.

From the results of the analysis, it can be said that the bank applies knowledge management processes in a high rate of $74 \%$.

\subsection{Testing The Differences Between Groups}

The research hypothesis regarding group differences state that: There are no differences between the average respondents' responses about knowledge management processes due to demographic data (gender, age, qualification and period of service at bank). 


\section{(i) Gender}

To find out if there is a statistically significant relationship, the chi-square test was used and the test results were as follow

Table 12. Gender and bank application of knowledge acquisition and creation activities

\begin{tabular}{|c|c|c|c|c|c|c|c|}
\hline \multirow[t]{2}{*}{ Gender } & \multicolumn{4}{|c|}{$\begin{array}{l}\text { To what extent does the bank perform knowledge creation and acquisition } \\
\text { activities? }\end{array}$} & \multirow[t]{2}{*}{ Total } & \multirow[t]{2}{*}{ Chi-Square } & \multirow[t]{2}{*}{ Sig } \\
\hline & Strongly disagree & neutral & agree & Strongly agree & & & \\
\hline Male & 0 & 0 & 16 & 12 & 28 & \multirow[t]{3}{*}{5.248} & \multirow[t]{3}{*}{0.155} \\
\hline Female & 1 & 4 & 13 & 12 & 30 & & \\
\hline Total & 1 & 4 & 29 & 24 & 58 & & \\
\hline
\end{tabular}

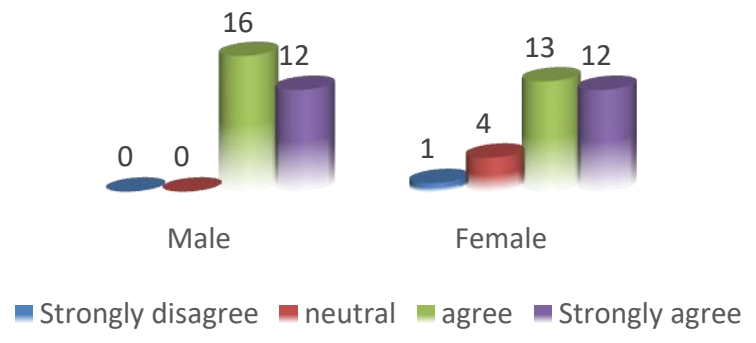

Fig.1. Gender and bank application of knowledge acquisition and creation activities

Table 12. and Figure 1. show independent Chi-Square test for gender and the bank application of knowledge acquisition and creation activities where the value of Chi-Square was 5.248 and critical probability Sig was 0.155 , as Sig is greater than 0.05 so the two variable are independent and there is no relation between Gender and The bank application of knowledge acquisition and creation activities.

Table 13. Gender and the bank application of knowledge storage activities

\begin{tabular}{|l|l|l|l|l|l|l|}
\hline \multirow{2}{*}{ Gender } & \multicolumn{2}{|l|}{ To what extent does the bank perform knowledge storage activities? } & & \multirow{2}{*}{ Total } & Chi-Square \\
\cline { 2 - 5 } & neutral & agree & Strongly agree & 28 & 1.937 \\
\hline Male & 3 & 11 & 14 & 30 & 0.380 \\
\hline Female & 7 & 12 & 11 & 58 & \\
\hline Total & 10 & 23 & 25 & \\
\hline
\end{tabular}

Fig.2. Gender and the bank application of knowledge storage activities

Table 13. and Figure 2. show independent Chi-Square test for gender the bank application of knowledge storage activities, where the value of Chi-Square was 1.937 and critical probability Sig was 0.380, as Sig greater than 0.05 so the two variable are independent and there is no relation between Gender and The bank application of knowledge storage activities.

Table 14. Gender and the bank application of knowledge sharing activities

\begin{tabular}{|c|c|c|c|c|c|c|c|}
\hline \multirow[t]{2}{*}{ Gender } & \multicolumn{4}{|c|}{$\begin{array}{l}\text { Please show to what extent does the bank perform knowledge sharing } \\
\text { activities? }\end{array}$} & \multirow[t]{2}{*}{ Total } & \multirow[t]{2}{*}{ Chi-Square } & \multirow[t]{2}{*}{ Sig } \\
\hline & disagree & neutral & agree & Strongly agree & & & \\
\hline Male & 0 & 1 & 13 & 14 & 28 & \multirow[t]{3}{*}{6.646} & \multirow[t]{3}{*}{0.084} \\
\hline Female & 5 & 3 & 12 & 10 & 30 & & \\
\hline Total & 5 & 4 & 25 & 24 & 58 & & \\
\hline
\end{tabular}




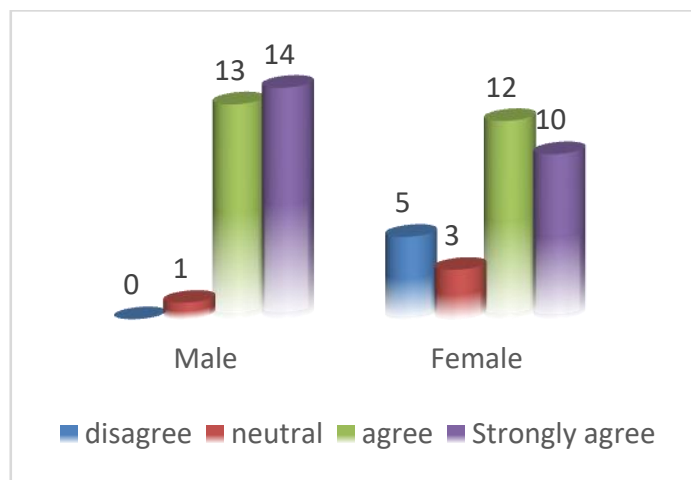

Fig.3. Gender and the bank application of knowledge sharing activities

Table 14. and Figure 3. show independent Chi-Square test for gender and the bank application of knowledge sharing activities, where the value of Chi-Square was 6.646 and critical probability Sig was 0.084, as Sig greater than 0.05 so the two variable are independent and there is no relation between gender and the bank application of knowledge sharing activities.

Table 15. Gender and the bank application of knowledge application activities

\begin{tabular}{|l|l|l|l|l|l|l|}
\hline \multirow{2}{*}{ Gender } & \multicolumn{2}{|l|}{$\begin{array}{l}\text { Please show to what extent does the bank perform knowledge } \\
\text { application activities? }\end{array}$} & \multirow{2}{*}{ Total } & \multirow{2}{*}{ Chi-Square } & \multirow{2}{*}{ Sig } \\
\cline { 2 - 4 } & neutral & agree & Strongly agree & & & \\
\hline Male & 3 & 12 & 13 & 28 & 0.446 & \multirow{2}{*}{0.800} \\
\hline Female & 4 & 14 & 11 & 29 & \\
\cline { 1 - 4 } Total & 7 & 26 & 24 & 57 & & \\
\hline
\end{tabular}

Fig.4. Gender and the bank application of knowledge application activities

Table 15. and Figure 4. show independent Chi-Square test for gender and the bank application of knowledge application activities, where the value of Chi-Square was 0.446 and critical probability Sig was 0.800 , as Sig greater than 0.05 so the two variable are independent and there is no relation between Gender and The bank application of knowledge application activities.

(ii) Age

To find out if there is a statistically significant relationship, the chi-square test was used and the test results were as follow

Table 16. Age and the bank application of knowledge acquisition and creation activities

\begin{tabular}{|c|c|c|c|c|c|c|c|}
\hline \multirow[t]{2}{*}{ Age } & \multicolumn{4}{|c|}{$\begin{array}{l}\text { Please show to what extent does the bank perform knowledge creation and } \\
\text { acquisition activities? }\end{array}$} & \multirow[t]{2}{*}{ Total } & \multirow[t]{2}{*}{ Chi-Square } & \multirow[t]{2}{*}{ Sig } \\
\hline & Strongly disagree & neutral & agree & Strongly agree & & & \\
\hline Less than 30 & 1 & 1 & 15 & 11 & 28 & \multirow[t]{5}{*}{5.731} & \multirow[t]{5}{*}{0.767} \\
\hline 30 - less than 40 & 0 & 3 & 9 & 8 & 20 & & \\
\hline $40-$ less than 50 & 0 & 0 & 5 & 4 & 9 & & \\
\hline more than 50 & 0 & 0 & 0 & 1 & 1 & & \\
\hline Total & 1 & 4 & 29 & 24 & 58 & & \\
\hline
\end{tabular}




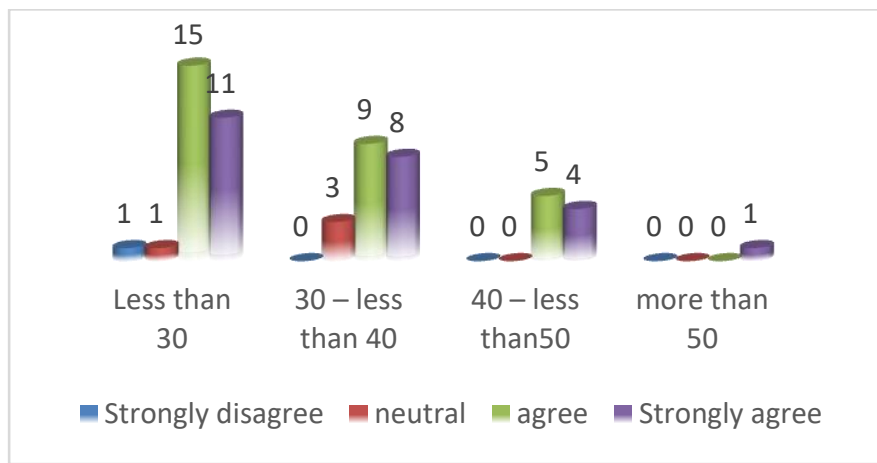

Fig.5. Age and the bank application of knowledge acquisition and creation activities

Table 16. and figure 5. show independent Chi-Square test for age and the bank application of knowledge acquisition and creation activities, Where the value of Chi-Square was 5.713 and critical probability Sig was 0.767 , as Sig greater than 0.05 so the two variable are independent and there are no relation between age and the bank application of knowledge acquisition and creation activities.

Table 17. Age and the bank application of knowledge storage activities

\begin{tabular}{|l|l|l|l|l|l|}
\hline \multirow{2}{*}{ Age } & \multicolumn{2}{|l|}{$\begin{array}{l}\text { Please show to what extent does the bank perform knowledge storage } \\
\text { activities? }\end{array}$} & Total & \multirow{2}{*}{ Chi-Square } \\
\cline { 2 - 5 } & neutral & agree & 13 & Strongly agree & \\
\hline Less than 30 & 4 & 6 & 9 & 28 & 3.318 \\
\hline $30-$ less than 40 & 5 & 4 & 4 & 20 & 9 \\
\hline $40-$ less than 50 & 1 & 0 & 1 & 1 & 5 \\
\hline more than 50 & 0 & 23 & 25 & 58 \\
\hline Total & 10 & & & \\
\hline
\end{tabular}

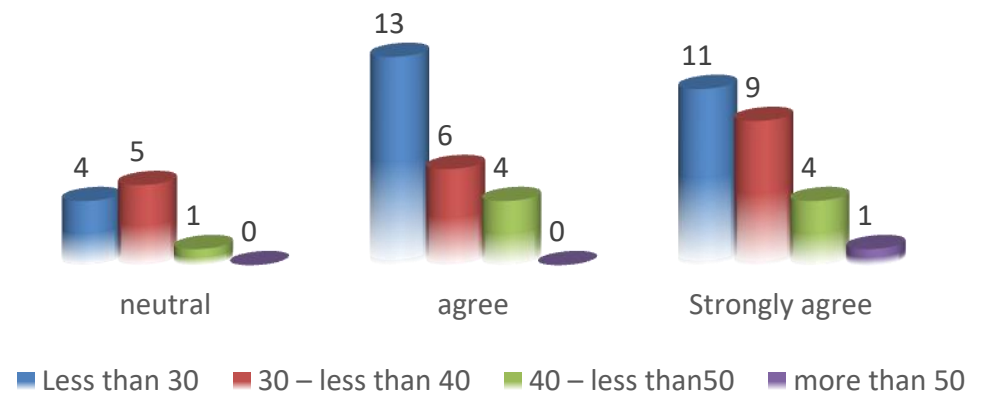

Fig.6. Age and the bank application of knowledge storage activities

Table 17. and Figure 6. show independent Chi-Square test for age and the bank application of knowledge storage activities, where the value of Chi-Square was 3.318 and critical probability Sig was 0.768 , as Sig greater than 0.05 so the two variables are independent and there is no relation between age and the bank application of knowledge storage activities.

Table 18. Age and the bank application of knowledge sharing activities

\begin{tabular}{|c|c|c|c|c|c|c|c|}
\hline \multirow[t]{2}{*}{ Age } & \multicolumn{4}{|c|}{$\begin{array}{l}\text { Please show to what extent does the bank perform knowledge sharing } \\
\text { activities? }\end{array}$} & \multirow[t]{2}{*}{ Total } & \multirow[t]{2}{*}{ Chi-Square } & \multirow[t]{2}{*}{ Sig } \\
\hline & disagree & neutral & agree & Strongly agree & & & \\
\hline Less than 30 & 3 & 2 & 13 & 10 & 28 & \multirow[t]{5}{*}{4.283} & \multirow[t]{5}{*}{0.892} \\
\hline $30-$ less than 40 & 2 & 2 & 7 & 9 & 20 & & \\
\hline $40-$ less than 50 & 0 & 0 & 4 & 5 & 9 & & \\
\hline more than 50 & 0 & 0 & 1 & 0 & 1 & & \\
\hline Total & 5 & 4 & 25 & 24 & 58 & & \\
\hline
\end{tabular}




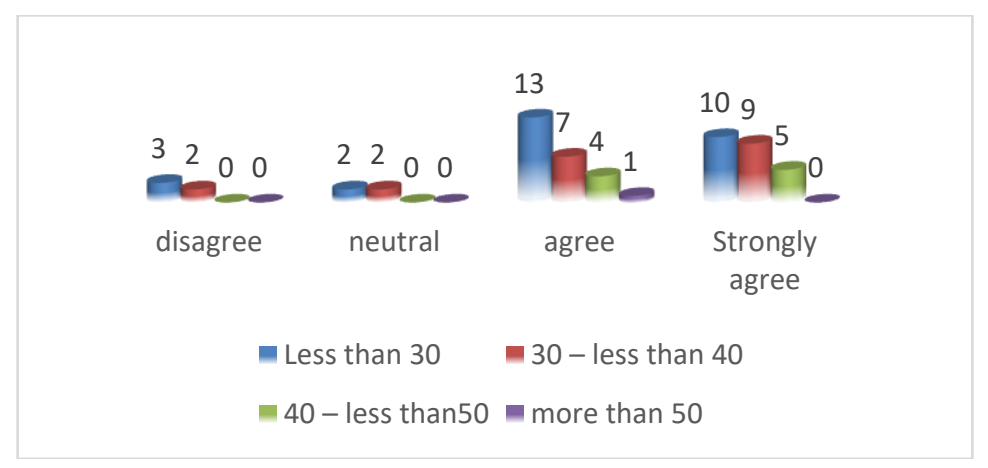

Fig.7. Age and the bank application of knowledge sharing activities

Table 18. and Figure 7. show independent Chi-Square test for age and the bank application of knowledge sharing activities, where the value of Chi-Square was 4.283 and critical probability Sig was 0.892 , as Sig greater than 0.05 so the two variable are independent and there is no relation between age and the bank application of knowledge sharing activities.

Table 19. Age and the bank application of knowledge application activities

\begin{tabular}{|l|l|l|l|l|l|}
\hline \multirow{2}{*}{ Age } & \multicolumn{2}{l|}{$\begin{array}{l}\text { Please show to what extent does the bank perform knowledge } \\
\text { application activities? }\end{array}$} & \multirow{2}{*}{ Total } & \multirow{2}{*}{ Chi-Square } \\
\cline { 2 - 5 } & neutral & agree & Strongly agree & \\
\hline Less than 30 & 2 & 14 & 11 & 27 & 0.113 \\
\hline $30-$ less than 40 & 2 & 10 & 8 & 20 & 9 \\
\hline $40-$ less than50 & 2 & 2 & 5 & 1 \\
\hline more than 50 & 1 & 0 & 0 & 57 \\
\hline Total & 7 & 26 & 24 & 5 \\
\hline
\end{tabular}

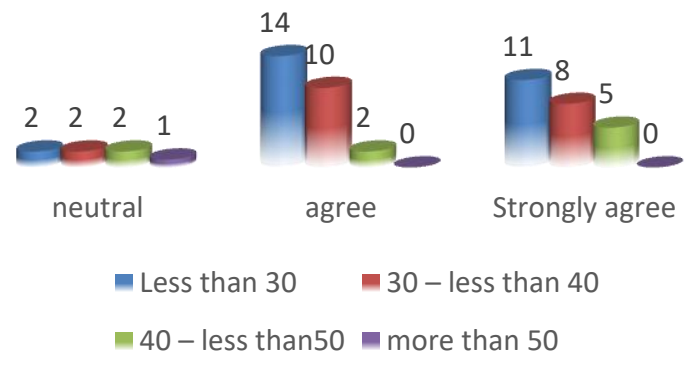

Fig.8. Age and The bank application of knowledge application activities

Table 19. and figure 8. show independent Chi-Square test for age and the bank application of knowledge application activities, where the value of Chi-Square was 10.288 and critical probability Sig was 0.113 , as Sig greater than 0.05 so the two variables are independent and there is no relation between age and the bank application of knowledge application activities.

\section{(iii) Qualification}

To find out if there is a statistically significant relationship, the chi-square test was used and the test results were as follow

Table 20. Qualification and bank application of knowledge acquisition and creation activities

\begin{tabular}{|c|c|c|c|c|c|c|c|}
\hline \multirow[b]{2}{*}{ Qualification } & \multicolumn{4}{|c|}{$\begin{array}{l}\text { Please show to what extent does the bank perform knowledge creation } \\
\text { and acquisition activities? }\end{array}$} & \multirow[t]{2}{*}{ Total } & \multirow{2}{*}{$\begin{array}{l}\text { Chi- } \\
\text { Square }\end{array}$} & \multirow[t]{2}{*}{ Sig } \\
\hline & $\begin{array}{l}\text { Strongly } \\
\text { disagree }\end{array}$ & neutral & agree & Strongly agree & & & \\
\hline Secondary & 0 & 0 & 1 & 0 & 1 & \multirow[t]{4}{*}{8.883} & \multirow[t]{4}{*}{0.180} \\
\hline University & 0 & 2 & 25 & 18 & 45 & & \\
\hline post graduate & 1 & 2 & 3 & 6 & 12 & & \\
\hline Total & 1 & 4 & 29 & 24 & 58 & & \\
\hline
\end{tabular}




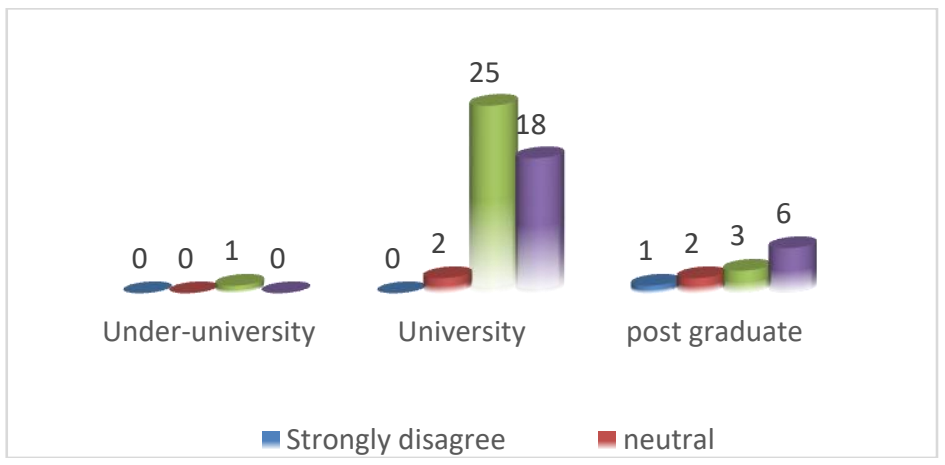

Fig.9. Qualification and bank application of knowledge acquisition and creation activities

Table 20. and Figure 9. show independent Chi-Square test for qualification and the bank application of knowledge acquisition and creation activities, where the value of Chi-Square was 8.883 and critical probability Sig was 0.180 , as Sig greater than 0.05 so the two variable are independent and there is no relation between qualification and the bank application of knowledge acquisition and creation activities.

Table 21. Qualification and the bank application of knowledge storage activities

\begin{tabular}{|c|c|c|c|c|c|c|}
\hline \multirow[t]{2}{*}{ Qualification } & \multicolumn{3}{|c|}{$\begin{array}{l}\text { Please show to what extent does the bank perform knowledge storage } \\
\text { activities? }\end{array}$} & \multirow[t]{2}{*}{ Total } & \multirow[t]{2}{*}{ Chi-Square } & \multirow[t]{2}{*}{ Sig } \\
\hline & neutral & agree & Strongly agree & & & \\
\hline Secondary & 1 & 0 & 0 & 1 & \multirow[t]{4}{*}{8.518} & \multirow[t]{4}{*}{0.074} \\
\hline University & 5 & 20 & 20 & 45 & & \\
\hline post graduate & 4 & 3 & 5 & 12 & & \\
\hline Total & 10 & 23 & 25 & 58 & & \\
\hline
\end{tabular}

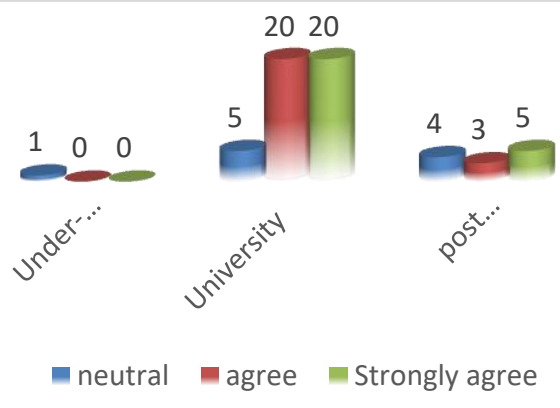

Fig.10. Qualification and the bank application of knowledge storage activities

Table 21 and Figure 10. show independent Chi-Square test for qualification and the bank application of knowledge storage activities, where the value of Chi-Square was 8.518 and critical probability Sig was 0.074 , as Sig greater than 0.05 so the two variable are independent and there is no relation between qualification and the bank application of knowledge storage activities.

Table 22. Qualification and the bank application of knowledge sharing activities

\begin{tabular}{|c|c|c|c|c|c|c|c|}
\hline \multirow[t]{2}{*}{ Qualification } & \multicolumn{4}{|c|}{$\begin{array}{l}\text { Please show to what extent does your bank perform knowledge sharing } \\
\text { activities? }\end{array}$} & \multirow[t]{2}{*}{ Total } & \multirow[t]{2}{*}{ Chi-Square } & \multirow[t]{2}{*}{ Sig } \\
\hline & disagree & neutral & agree & Strongly agree & & & \\
\hline Secondary & 0 & 0 & 1 & 0 & 1 & \multirow[t]{4}{*}{3.775} & \multirow[t]{4}{*}{0.707} \\
\hline University & 3 & 3 & 18 & 21 & 45 & & \\
\hline post graduate & 2 & 1 & 6 & 3 & 12 & & \\
\hline Total & 5 & 4 & 25 & 24 & 58 & & \\
\hline
\end{tabular}




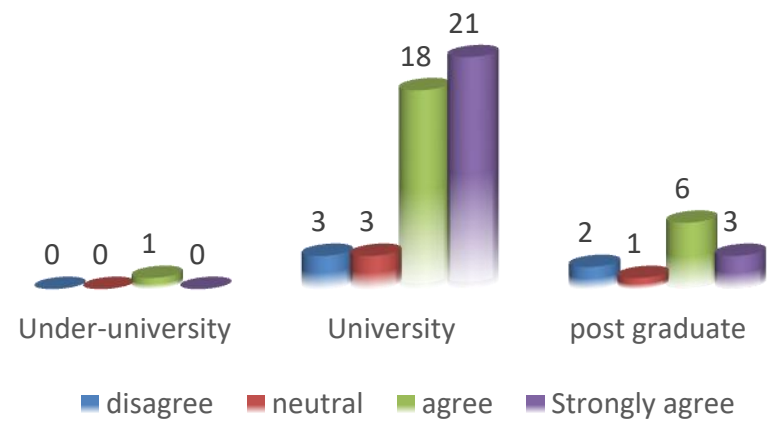

Fig.11. Qualification and the bank application of knowledge sharing activities

Table 22. and Figure 11. show independent Chi-Square test for qualification and the bank application of knowledge sharing activities, where the value of Chi-Square was 3.775 and critical probability Sig was 0.707, as Sig greater than 0.05 so the two variable are independent and there is no relation between qualification and the bank application of knowledge sharing activities.

Table 23. Qualification and the bank application of knowledge application activities

\begin{tabular}{|c|c|c|c|c|c|c|}
\hline \multirow[t]{2}{*}{ Qualification } & \multicolumn{3}{|c|}{$\begin{array}{l}\text { Please show to what extent does your bank perform } \\
\text { knowledge application activities? }\end{array}$} & \multirow[t]{2}{*}{ Total } & \multirow[t]{2}{*}{ Chi-Square } & \multirow[t]{2}{*}{ Sig } \\
\hline & neutral & agree & Strongly agree & & & \\
\hline secondary & 0 & 1 & 0 & 1 & \multirow[t]{4}{*}{7.798} & \multirow[t]{4}{*}{0.099} \\
\hline University & 3 & 20 & 21 & 44 & & \\
\hline post graduate & 4 & 5 & 3 & 12 & & \\
\hline Total & 7 & 26 & 24 & 57 & & \\
\hline
\end{tabular}

Fig.12. Qualification and the bank application of knowledge application activities

Table 23. and Figure 12. show independent Chi-Square test for qualification and the bank application of knowledge application activities, where the value of Chi-Square was 7.789 and critical probability Sig was 0.099, as Sig greater than 0.05 so the two variable are independent and there is no relation between qualification and the bank application of knowledge application activities

\section{(iv) Period of service in Bank}

To find out if there is a statistically significant relationship, the chi-square test was used and the test results were as follow

Table 24. Period of service in bank and the bank application of knowledge acquisition and creation activities

\begin{tabular}{|c|c|c|c|c|c|c|c|}
\hline \multirow[t]{2}{*}{ Period of service in bank } & \multicolumn{4}{|c|}{$\begin{array}{l}\text { Please show to what extent does your bank perform knowledge } \\
\text { acquisition and creation activities? }\end{array}$} & \multirow[t]{2}{*}{ Total } & \multirow[t]{2}{*}{ Chi-Square } & \multirow[t]{2}{*}{ Sig } \\
\hline & Strongly disagree & neutral & agree & Strongly agree & & & \\
\hline Less than 3 years & 1 & 0 & 12 & 10 & 23 & \multirow[t]{4}{*}{4.833} & \multirow[t]{4}{*}{0.585} \\
\hline 3 - less than 7 & 0 & 2 & 6 & 7 & 15 & & \\
\hline more than 7 & 0 & 2 & 10 & 7 & 19 & & \\
\hline Total & 1 & 4 & 28 & 24 & 57 & & \\
\hline
\end{tabular}




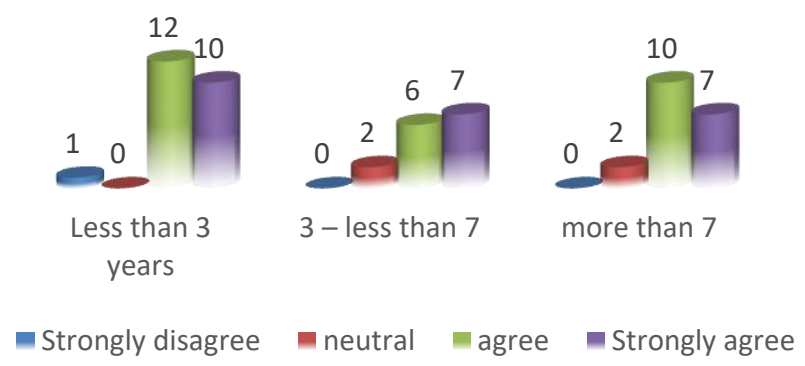

Fig.13. Period of service in bank and the bank application of knowledge acquisition and creation activities

Table 24. and Figure 13. show independent Chi-Square test for period of service in bank and the bank application of knowledge acquisition and creation activities, where the value of Chi-Square was 4.833 and critical probability Sig was 0.585 , as Sig greater than 0.05 so the two variable are independent and there is no relation between Period of service in bank and the bank application of knowledge acquisition and creation activities.

Table 25. Period of service in bank and the bank application of knowledge storage activities

\begin{tabular}{|c|c|c|c|c|c|c|}
\hline \multirow[t]{2}{*}{ Period of service in bank } & \multicolumn{3}{|c|}{$\begin{array}{l}\text { Please show to what extent does the bank perform knowledge storage } \\
\text { activities? }\end{array}$} & \multirow[t]{2}{*}{ Total } & \multirow[t]{2}{*}{ Chi-Square } & \multirow[t]{2}{*}{ Sig } \\
\hline & neutral & agree & Strongly agree & & & \\
\hline Less than 3 years & 2 & 11 & 10 & 23 & \multirow[t]{4}{*}{2.988} & \multirow[t]{4}{*}{0.560} \\
\hline 3 - less than 7 & 4 & 4 & 7 & 15 & & \\
\hline more than 7 & 4 & 7 & 8 & 19 & & \\
\hline Total & 10 & 22 & 25 & 57 & & \\
\hline
\end{tabular}

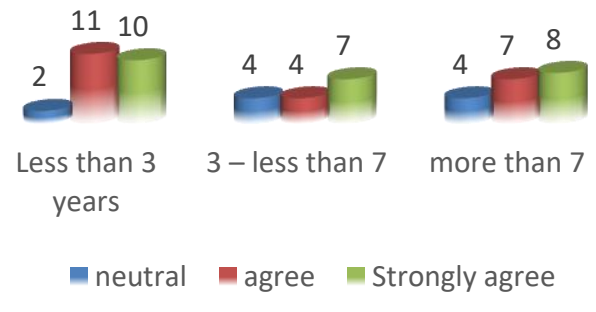

Fig.14. Period of service in bank and the bank application of knowledge storage activities

Table 25. and Figure 14. show independent Chi-Square test for period of service in bank and the bank application of knowledge storage activities, where the value of Chi-Square was 2.988 and critical probability Sig was 0.560 , as Sig greater than 0.05 so the two variable are independent and there is no relation between Period of service in bank and the bank application of knowledge storage activities.

Table 26. Period of service in bank and the bank application of knowledge sharing activities

\begin{tabular}{|c|c|c|c|c|c|c|c|}
\hline \multirow[t]{2}{*}{ Period of service in bank } & \multicolumn{4}{|c|}{$\begin{array}{l}\text { Please show to what extent does the bank perform knowledge sharing } \\
\text { activities? }\end{array}$} & \multirow[t]{2}{*}{ Total } & \multirow[t]{2}{*}{ Chi-Square } & \multirow[t]{2}{*}{ Sig } \\
\hline & disagree & neutral & agree & Strongly agree & & & \\
\hline Less than 3 years & 2 & 1 & 11 & 9 & 23 & \multirow[t]{4}{*}{1.154} & \multirow[t]{4}{*}{0.979} \\
\hline 3 - less than 7 & 1 & 1 & 6 & 7 & 15 & & \\
\hline more than 7 & 2 & 2 & 7 & 8 & 19 & & \\
\hline Total & 5 & 4 & 24 & 24 & 57 & & \\
\hline
\end{tabular}




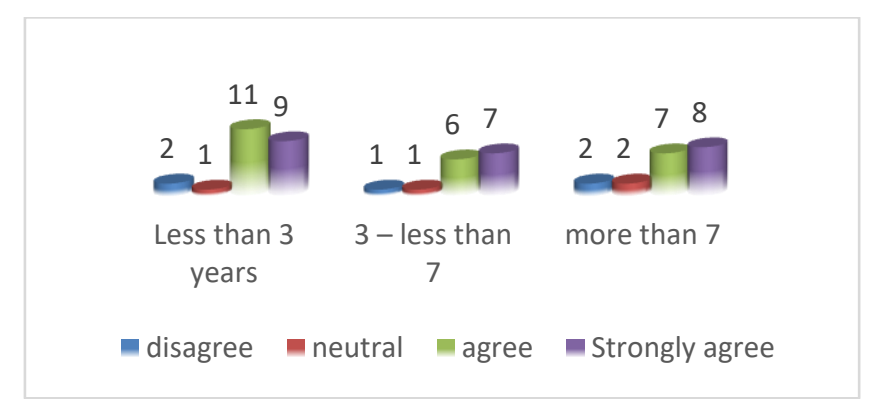

Fig.15. Period of service in bank and the bank application of knowledge sharing activities

Table 26. and Figure 15. show independent Chi-Square test for period of service in bank and the bank application of knowledge sharing activities, where the value of Chi-Square was 1.154 and critical probability Sig was 0.979 , as Sig greater than 0.05 so the two variable are independent and there is no relation between Period of service in bank and the bank application of knowledge sharing activities.

Table 27. Period of service in bank and the bank application of knowledge application activities

\begin{tabular}{|c|c|c|c|c|c|c|}
\hline \multirow[t]{2}{*}{ Period of service in bank } & \multicolumn{3}{|c|}{$\begin{array}{l}\text { Please show to what extent does the bank perform knowledge } \\
\text { application activities? }\end{array}$} & \multirow[t]{2}{*}{ Total } & \multirow{2}{*}{$\begin{array}{l}\text { Chi- } \\
\text { Square }\end{array}$} & \multirow[t]{2}{*}{ Sig } \\
\hline & neutral & agree & Strongly agree & & & \\
\hline Less than 3 years & 0 & 12 & 10 & 22 & \multirow[t]{4}{*}{7.169} & \multirow[t]{4}{*}{0.127} \\
\hline 3 - less than 7 & 4 & 4 & 7 & 15 & & \\
\hline more than 7 & 3 & 9 & 7 & 19 & & \\
\hline Total & 7 & 25 & 24 & 56 & & \\
\hline
\end{tabular}

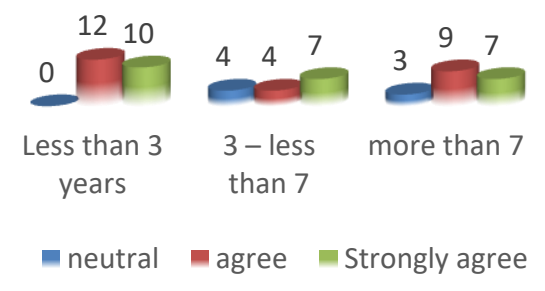

Fig.16. Period of service in bank and the bank application of knowledge application activities

Table 27. and Figure 16. show independent Chi-Square test for period of service in bank and the bank application of knowledge application activities, where the value of Chi-Square was 7.169 and critical probability Sig was 0.127 , as Sig greater than 0.05 so the two variable are independent and there is no relation between Period of service in bank and the bank application of knowledge application activities.

\section{(v) Results Summary}

The research relied on the questionnaire as the main tool for data collection. The study population consisted of bank employees in their various positions. A total of 60 questionnaires were distributed, of which 58 were returned for statistical analysis. The results of the study followed standard methodology based on the state of the arts researches. The study found that the degree of application of knowledge management was medium in the field of knowledge creation and acquisition, reaching $68 \%$ and high in the field of knowledge storage $74 \%$, knowledge sharing $76 \%$ and knowledge application $77 \%$. The results also showed that there were no statistical differences related to gender, age, academic qualification and period of service.

\section{Conclusion}

Knowledge has been recognized as one of the most critical resources for all types of organizations to achieve competitive advantage and to be innovative. Knowledge is not easily measured or audited, so organizations need to efficiently manage knowledge to take full advantage of their skills and experience inherent in their systems and structures, as well as the knowledge of the employees of the institution. Knowledge management is the ability to link structured and unstructured information with the changing rules by which people apply it, it's not a technology, but a strategic solution that applies information technologies. The aim of this study was to assess the extent to which knowledge management is applied in Sudanese banks. The four main processes of knowledge management were 
considered in this study (knowledge creation and acquisition, knowledge storage, knowledge sharing and knowledge application). The study used the descriptive analytical approach to investigate the research questions. The study population consisted of bank employees in their various positions. A total of 60 questionnaires were distributed, of which 58 were returned for statistical analysis. The results of the study followed standard methodology based on the state of the arts researches. The results of the study showed that the application of knowledge management concept practices is high; there is an application of the concept of knowledge management in the Farmer's Commercial Bank with a high rate of $74 \%$.

The study recommends:

- Employees should be given the freedom to organize and carryout the job by methods and means they believe appropriate.

- The bank should seek the help of external experts to transfer their knowledge to employees.

- The knowledge of experts in each department should be documented and organized to be used as base for problem solving.

- Knowledge management strategy: to initiate knowledge management program in the bank, it is very important to formulate a knowledge management strategy with a clear vision, expected outcomes and an evaluation plan.

- Management support and commitment: management should consider knowledge management as one of their priorities and allocate the necessary KM infrastructure including technological infrastructure and sufficient budget.

- Staff training: it is necessary to held training courses to employees to recognize knowledge management concept and its importance to better understand their role in KM.

- Rewards and incentives: rewards and incentives are the biggest motivations, so there should be an appropriate rewards and incentive to encourage employees to create and share knowledge to improve services.

- Culture: developing the right culture for knowledge sharing, this could be done by maintain trust, respect between employees. Knowledge sharing culture is very important for the success of knowledge management program because it encourages staff to create, share, and participate. The success of any knowledge management project depends on the strong collaboration between staff.

\section{References}

[1] S. P. Webb, Knowledge management: Linchpin of change: Routledge, 2017.

[2] A. M. Abubakar, H. Elrehail, M. A. Alatailat, and A. Elçi, "Knowledge management, decision-making style and organizational performance," Journal of Innovation \& Knowledge, vol. 4, pp. 104-114, 2019.

[3] J. Ferreira, J. Mueller, and A. Papa, "Strategic knowledge management: theory, practice and future challenges," Journal of knowledge management, 2018.

[4] E. Bolisani and C. Bratianu, "The emergence of knowledge management," in Emergent knowledge strategies, ed: Springer, 2018, pp. 23-47.

[5] S. Abualoush, R. Masa'deh, K. Bataineh, and A. Alrowwad, "The role of knowledge management process and intellectual capital as intermediary variables between knowledge management infrastructure and organization performance," Interdisciplinary Journal of Information, Knowledge, and Management, vol. 13, pp. 279-309, 2018.

[6] A. Mardani, S. Nikoosokhan, M. Moradi, and M. Doustar, "The relationship between knowledge management and innovation performance," The Journal of High Technology Management Research, vol. 29, pp. 12-26, 2018.

[7] R. Dayan, P. Heisig, and F. Matos, "Knowledge management as a factor for the formulation and implementation of organization strategy," Journal of Knowledge Management, 2017.

[8] A. N. H. Zaied, G. S. Hussein, and M. M. Hassan, "The role of knowledge management in enhancing organizational performance," International Journal of Information Engineering and Electronic Business, vol. 4, p. $27,2012$.

[9] A. N. H. Zaied, "An integrated knowledge management capabilities framework for assessing organizational performance," International Journal of Information Technology and Computer Science, vol. 4, pp. 1-10, 2012.

[10] Z. Xiuxu and Z. Yuming, "Application research of ontology-enabled process FMEA knowledge management method," Int. J. Intelligent Systems and Applications, pp. 34-40, 2012.

[11] V. Keishing and S. Renukadevi, "A Review of Knowledge Management Based Career Exploration System in Engineering Education," International Journal of Modern Education \& Computer Science, vol. 8, 2016.

[12] G. Biswakarma, "Knowledge management and employee job performance in nepalese banking sector," International Journal of Research in, 2018.

[13] A. Iqbal, F. Latif, F. Marimon, U. F. Sahibzada, and S. Hussain, "From knowledge management to organizational performance," Journal of Enterprise Information Management, 2019.

[14] M. Al-Emran, V. Mezhuyev, A. Kamaludin, and K. Shaalan, "The impact of knowledge management processes on information systems: A systematic review," International Journal of Information Management, vol. 43, pp. 173-187, 2018.

[15] R. Lashari and A. H. Rana, "The impact of transformational leadership and social interaction on organizational performance in the viewpoint of knowledge management: an empirical study in banking sector of Pakistan," International Journal of Organizational Leadership, vol. 7, pp. 383-397, 2018.

[16] F. Campanella, A. Derhy, and F. Gangi, "Knowledge management and value creation in the post-crisis banking system," Journal of Knowledge Management, 2019. 
[17] H. El-Chaarani and Z. El-Abiad, "Knowledge management and job performance: The case of lebanese banking sector," International Review of Management and Marketing, vol. 10, pp. 91-98, 2020.

[18] B. Bidabad, "CHANGE MANAGEMENT OF BANKING SYSTEM AT NATIONAL LEVEL BY RASTIN BANKING: KNOWLEDGE MANAGEMENT, EMPOWERMENT, PRUNE AND GRAFT, AND APPRENTICESHIP," Review of Behavioral Aspect in Organizations and Society, vol. 1, pp. 57-70, 2019.

[19] B. M. Al-Abdullat and A. Dababneh, "The mediating effect of job satisfaction on the relationship between organizational culture and knowledge management in Jordanian banking sector," Benchmarking: An International Journal, 2018.

[20] M. K. Okour, C. W. Chong, and A. Asmawi, "Antecedents and consequences of knowledge management systems usage in J ordanian banking sector," Knowledge and Process Management, vol. 26, pp. 10-22, 2019.

[21] V. Stojanović-Aleksić, J. E. Nielsen, and A. Bošković, "KNOWLEDGE MANAGEMENT: EVIDENCE FROM SERBIAN BANKING SECTOR," Facta Universitatis, Series: Economics and Organization, pp. 189-201, 2018.

[22] M. La Torre, "Knowledge Management, Risk Management, Knowledge Risk Management: What Is Missing (or Messed) in Financial and Banking Sectors," in Risk in Banking, ed: Springer, 2020, pp. 39-71.

[23] K. N. N. Soe and A. C. Aye, "The Mediating Role of Job Satisfaction on The Relationship between Knowledge Management Practices and Employee Work Performance: The Private Banking Case in Myanmar," TNI Journal of Business Administration and Languages, vol. 8, pp. 83-97, 2020.

[24] N. Nurdin and K. Yusuf, "Knowledge management lifecycle in Islamic bank: the case of syariah banks in Indonesia," International Journal of Knowledge Management Studies, vol. 11, pp. 59-80, 2020.

[25] A. Mehrotra, "Geospatial Knowledge Management-Fresh Fuel for Banking and Economic Growth?," in Computational Methods and Data Engineering, ed: Springer, 2020, pp. 53-65.

[26] A. Kumari and T. Saharan, "Knowledge Management as a Catalyst to Sustainable Development in Banking Industry," in 2020 International Conference on Computer Science, Engineering and Applications (ICCSEA), 2020, pp. 1-6.

[27] E. Ode and R. Ayavoo, "The mediating role of knowledge application in the relationship between knowledge management practices and firm innovation," Journal of Innovation \& Knowledge, vol. 5, pp. 210-218, 2020.

[28] N. Andleeb, M. F. Ahmad, and S. Aziz, "Organizational Culture and Knowledge Sharing in Banking Management," in Banking and Finance, ed: IntechOpen, 2020.

[29] C. J. Katua, "A framework for applying knowledge management in organizations in Kenya," University of Nairobi, 2010.

[30] J. C. Rono, "Knowledge management practices by commercial banks in Kenya," 2011.

[31] N. F. Easa, "Knowledge management and the SECI model: a study of innovation in the Egyptian banking sector," 2012.

[32] Z. Sadq, B. Othman, and H. Mohammed, "Attitudes of managers in the Iraqi Kurdistan region private banks towards the impact of knowledge management on organizational effectiveness," Management Science Letters, vol. 10, pp. 1835-1842, 2020.

[33] M. I. Hanif, N. Waheed, and S. Ahmad, "Organizational Commitment \& Work Engagement Affected by Knowledge management: Evidence from banking sector of Pakistan," Sarhad Journal of Management Sciences, vol. 6, pp. 99-114, 2020.

[34] H. Fahad, "Knowledge Management Capability, Top Management Team Demographics and Market Capitalizing Agility in the Banking Sector of the Kingdom of Saudi Arabia," Journal of International Business, Innovation and Strategic Management, vol. 4, pp. 47-65, 2020.

\section{Authors' Profiles}

Ryan Abdalgader obtained her MSc. in Banking Information Systems from Sudan Academy for Banking and Financial Sciences in 2020, her research interests include banking information systems, web programming and knowledge Management.

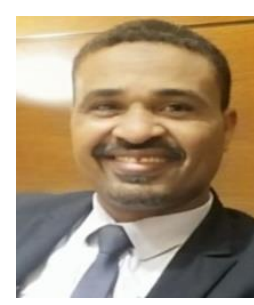

Adil Yousif received the B.Sc. and M.Sc. from University of Khartoum, Sudan, and his PhD degree from UTM, University of Technology in Malaysia. He is now Associate Professor at Faculty of Arts and Sciences Sharourah, Najran University, Saudi Arabia. He has published more than forty papers in international journals and conferences. His research interests include computer networks, cloud computing, grid computing and optimization techniques.

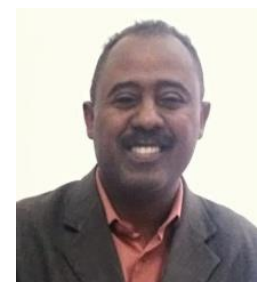

TajElsir Hassan Suliman has obtained his $\mathrm{PhD}$ in Distributed Mobility Management (DMM) from Sudan University of Science and Technology(Sudan) in 2016, his research interests include DMM, wireless networks, information security, cloud security. He has more than 20 years of teaching experience and has supervised more than 20 MSc. Research students in different fields of computer science. Now he is IT Programme coordinator at Sudan Academy for Banking and Financial Sciences, Sudan. 
How to cite this paper: Rayan Abdelgader Elhassan, Adil Yousif, TajElsir Hassan Suliman, " Assessment of Knowledge Management Application in Banking Sector of Sudan: Case Study Farmer's Commercial Bank", International Journal of Information Engineering and Electronic Business(IJIEEB), Vol.13, No.4, pp. 1-19, 2021. DOI: 10.5815/ijieeb.2021.04.01 